Article

\title{
Experiences, Motivations, Perceptions, and Attitudes Regarding Ethnic Minority Village Tourism
}

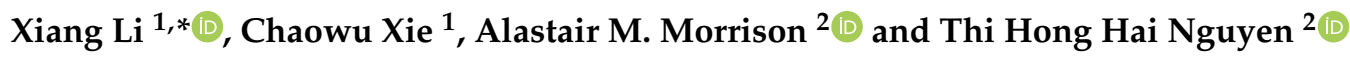 \\ 1 College of Tourism, Huaqiao University, Quanzhou 362021, China; xiecwu@126.com \\ 2 Department of Marketing, Events and Tourism, Business School, University of Greenwich, \\ London SE10 9SL, UK; a.morrison@greenwich.ac.uk (A.M.M.); T.H.H.Nguyen@greenwich.ac.uk (T.H.H.N.) \\ * Correspondence: ilee730@163.com
}

check for updates

Citation: Li, X.; Xie, C.; Morrison, A.M.; Nguyen, T.H.H. Experiences, Motivations, Perceptions, and Attitudes Regarding Ethnic Minority Village Tourism. Sustainability 2021,

13, 2364. https://doi.org/ $10.3390 /$ su13042364

Academic Editor: Colin Michael Hall

Received: 23 January 2021

Accepted: 18 February 2021

Published: 22 February 2021

Publisher's Note: MDPI stays neutral with regard to jurisdictional claims in published maps and institutional affiliations.

Copyright: (c) 2021 by the authors. Licensee MDPI, Basel, Switzerland. This article is an open access article distributed under the terms and conditions of the Creative Commons Attribution (CC BY) license (https:// creativecommons.org/licenses/by/ $4.0 /)$.

\begin{abstract}
Ethnic minority villages are a vital part of tourism in certain destinations, often attracting many domestic and international visitors to experience unique local cultures and authentic lifestyles. However, much of the relevant literature has not examined tourist motivations, perceptions, and attitudes regarding ethnic minority village tourism. This exploratory qualitative research analyzed user-generated blogs uploaded by people sharing their ethnic minority village experiences in Guizhou Province, China. ROST Content Mining6 software was employed to identify motivations, perceptions, and attitudes toward minority village tourism. The findings indicated that tourist experience included natural aesthetic, cultural aesthetic, service and interaction, and entertainment. The main motivation was to experience unique cultural activities. The strongest perceptions were of the local villagers, Miao and Dong family life, and tourism services and environments. Tourist attitudes were mostly positive. Suggestions for better satisfying tourist needs and improving experiences were derived from the data.
\end{abstract}

Keywords: ethnic tourism; ethnic minority village tourism; tourist experience; motivations; perceptions; attitudes

\section{Introduction}

Ethnic villages are highly valued by domestic tourists [1]. As windows to minority cultures, ethnic villages are unique attractions in several Asian and African countries, as well as other parts of the world. They encourage the retention of traditional lifestyles and cultures, while also being a source of economic benefits. In China, these ethnic settlements are located within natural settings in the countryside that are inhabited by large, relatively concentrated minority groups and have complete economic production (usually agricultural) and residential capacities [2]. Ethnic village tourism is an activity in which people visit places inhabited by ethnic minorities for sightseeing and experiencing authentic cultures [3].

Previous tourism researchers have described the development and management of ethnic village tourism, principally focusing on basic characteristics, i.e., definitions, types, and resources of ethnic village tourism [3,4]. Researchers have also focused on development models for ethnic village tourism [5], tourism development [6-8], construction of villages based on local ethnic tangible and intangible heritage and culture [9], community participation [10], community resident interests [11,12], and satisfaction [13].

However, tourist motivations, perceptions, and attitudes regarding ethnic minority village tourism have rarely been investigated. Analyzing these factors can help predict future tourist behavior, which can assist with refining village tourism products to satisfy the increasing tourist demand. As such, this was the major purpose of the current investigation. This research focused on ethnic minority villages and used content analysis of travel blogs to examine visitor motivations, perceptions, and attitudes regarding these communities. 
The rich contextual data obtained allowed the exploration of the feelings of people visiting ethnic minority villages.

\section{Literature Review}

The literature was carefully analyzed as the foundation for preparing our research design and methods. The following literature review begins with a description of the main constructs (tourist experience, motivations, perceptions, and attitudes). Then, the contexts for this research are explained through a review of the literature on ethnic and ethnic minority village tourism, followed by detailing the specific situation in Guizhou Province.

\subsection{Tourist Experience}

The tourist experience is a widely researched yet complicated concept due to the differing perspectives and persistent ambiguity of the topic. Multiple definitions of the tourist experience have been proposed by many scholars. Maccannell [14] described the tourist experience as a process. Cohen [15] characterized the tourist experience as a relationship between a modern person and various "centers", which are close to tourist feelings. Ryan [16] defined the tourist experience as a multi-functional leisure activity, including entertainment and learning. A common denominator is that the tourist experience is multifaceted and subjective.

Scholars have analyzed various types of tourist experiences, such as customer experiences [17], ethnic tourism experiences [18], hitchhiking tourism experiences [19], memorable tourism experiences [20], and traditional costume experiences [21]. The connotation, classification, and application of the tourist experience have been extensively studied. The tourist experience is comprehensive and diverse depending on the many combinations of tourists and destinations. However, there are few studies on the structure of the tourist experience when travelling to ethnic minority villages.

\subsection{Tourist Motivations}

As is the case with the tourist experience, there are multiple concepts for tourist motivations including those proposed by Crompton [22], Dann [23], Iso-Ahola [24], Pearce and Lee [25], and others. It could be an inner state that strengthens human behavior and act as the driving force behind actions [22,24,26,27]. Tourist motivations can be divided into four types: spirituality, social status, escape, and cultural enrichment [28]. It can further be divided into five types: physical, cultural, interpersonal, prestige, and selfactualization [29]. In addition, scholars have divided the tourist motivation according to the tourism destinations [30,31], specific groups [32-34], and specific tourism activities [35-37]. Although there is great diversity in these approaches, a consensus seems to be emerging that some motives are internal ("push") and others are external, including the "pull" of destinations.

The "push" motivations include socio-psychological and socio-cultural factors. The socio-psychological motives comprise escaping from every day and familiar environments, seeking and evaluating oneself, relaxing, prestige, improving relationships among relatives and friends, and strengthening social communication. The socio-cultural motives include novelty and education [22]. For example, Caber and Albayrak [38] identified the motivations of rock climbing tourists by using Dann's push and pull framework, and they found that the pursuit of challenges was one of the most powerful motivations for these tourists to climb and it affected experience levels. Bideci and Albayrak [31] found that interest in destination culture was a significant motive for people to travel, although its importance varied with demographic characteristics such as gender and age. Marques et al. [39] explored the travel motives of students from different countries and the results showed significant differences, which included discovering new cultures and places, exploring new ideas, relaxing, challenging and enjoying the place, social connections, and enhancing knowledge. 
The "pull motivations" are features and characteristics of destinations that are attractive and appeal to tourists [40]. Klenosky and David [40] analyzed several previous studies identified histories, heritages, and cultures, among many other pull factors of destinations. Kulczyk-Dynowska and Gaura [41] hold that the initiated activities, as well as the tourist function, could stimulate tourists' desire to travel.

\subsection{Tourist Perceptions}

Perceptions are cognitive reflections caused by external stimuli directly acting on sensory organs (Goldstein [42]). They are the mental interpretation of an individual's experiences and may be substantially different from reality [43]. Perception is a series of processes that organize and explain sensory information generated by external objects and events [42]. Tourist perceptions represent the psychological process of the perception of information such as objects and environmental conditions at destination through the senses. It is a comprehensive reflection at a cognitive level of destination products and services [44]. Tourist perceptions include the impressions of the culture of destinations through sensory experiences from participating in tourism activities [45].

There have been many studies on perceptions in China; however, these have tended to be more on the supply side and particularly with a focus on resident perceptions. On the demand side, perceived value research involves consumer perceptions of service quality and the value of cultural products [46]; relationships among the influencing factors of purchases and motivation [47]; motivations and development strategy of villages [48]; differences in tourist perceived value [49,50]; and public perceived value [51]. Su et al. [52] found that ethnic encounters were not perceived by tourists as a primary motivation to visit ethnic minority villages, but residents' support, including attitude support (AS), intention support (IS), and behavioral support (BS) [53] could contribute to the formation of satisfactory on-site experiences. Perceptual images of specific cases have been determined. For example, Qu and Liang [54] studied tourist perceptions of Guangzhou's image through online travel blogs. Cai and Lai [55] took Guangzhou as the case to analyze tourist perceptions of food culture landscapes. Further, Lei et al. [56] divided national images in tourism into the two categories of macro and micro, comparing the perceptions of national images of college students in three different countries from these two viewpoints.

\subsection{Tourist Attitudes}

Attitudes are psychological tendencies, expressed by individuals through positive or negative evaluations of objects or experiences [57]. Research on attitudes from various perspectives has received considerable attention in tourism. For example, the impact of attitudes on travel destination choice has been investigated [58]. Cho et al. [59] explored sport tourist nostalgia and its effect on attitudes and intentions, showing that the relationship between nostalgia and intentions was fully mediated by attitudes. In addition, consumption value was found to effectively explain tourist attitudes toward destination image and behavioral intentions [60]. Bajada and Titheridge [61] concluded that the quality of public services in destinations affected tourist attitudes, including the public transportation system.

Tourist attitudes can be determined through the analysis of nouns and adjectives cited by them in blogs or in the evaluations of impressions and feelings toward destinations or scenic spots [45]. These describe psychological tendencies through positive or negative evaluations of the destination experience [62].

Given the above, this study proposes the following: tourist behavior is influenced by motivations, perceptions, and attitudes. Tourist motivation stimulates action, which is the psychological tendency or internal driving force for behavior. Moreover, perceptions of tourism attractions affect people's attitudes. The context for tourist behavior is also of great significance and related to the "pull" motivational factors. Therefore, the specific contexts for this research are now reviewed. 


\subsection{Ethnic Minority Village Tourism}

\subsubsection{Ethnic Tourism}

Ethnic tourism refers to a type of tourism that involves "quaint" customs of indigenous and exotic people [63]. It is often discussed as a link between tourism and ethnicity [64], where ethnicity has been commodified and marketed as a product to tourists [65]. It is also defined as a type of tourism where people are motivated by their search for exotic cultural experiences [66]. The main attraction of ethnic tourism is thus the cultural exoticism, especially of minority groups as perceived by the dominant majority society $[67,68]$. Hence, the minority ethnic people and their lifestyles are observed, photographed, and especially interacted with as living spectacles. With the development of ethnic tourism, ethnic people and cultures are not only seen in their remote villages, but ethnic products are also offered at cultural parks in cities [69]. Ultimately, experiencing ethnic culture is an important motivation and tourist-community interactions are a fundamental aspect [52].

Various alternate terms are used in place of "ethnic tourism", such as "aboriginal tourism", "indigenous tourism", "heritage tourism", "village tourism", "rural tourism", and others. While these terms are interrelated and somewhat overlapping, they should be differentiated. First, the terms "aboriginal tourism" and "indigenous tourism" are sometimes used interchangeably with "ethnic tourism" [64]. However, the major difference is that while indigenous people are the essential element of aboriginal and indigenous tourism, ethnic tourism activities are not necessarily based on indigenous features [64]. Second, ethnic tourism often takes place in rural and village contexts, hence it is sometimes referred to as rural or village tourism. These forms of tourism can be overlapping, yet their focus is not the same. The former centers on ethnicity [64], while the latter is based on rural or village lifestyles and landscapes [70]. Third, ethnic tourism is based on exotic cultures and customs, and thus it is connected to cultural and heritage tourism. Ethnic tourism is indeed within the realm of cultural and heritage tourism, where ethnicity is at the center of tourism activities. Additionally, Wood [68] asserts that ethnic tourism provides a more "intimate" and "authentic" experience of another culture than cultural tourism.

Research on ethnic tourism often focuses on its impacts on local ethnic communities, revealing both positive and negative aspects [71]. On the positive side, it provides local ethnic groups the opportunities to showcase their cultures, contributes to reviving cultures, strengthen identities, and promotes the appreciation and respect for ethnic cultures [52,64,72]. However, ethnic tourism activities can exert negative socio-cultural impacts including the commoditization of culture, degradation of culture, and the loss of traditions [73]. These impacts can be elevated or minimized with careful planning and the involvement of all stakeholders, including local ethnic groups. Importantly, limited attention has been given to the study of tourist perspectives on ethnic tourism [71]. Several topics being discussed include the issue of authentic experiences [64,71], segmentation of ethnic tourists [74-76], tourist-community interactions [52,77], and ethnic tourist experience and satisfaction $[64,78]$.

While in general ethnic tourism might not be an especially popular research topic, the majority of related studies are in a Chinese context (with more than half of the search results of articles on this topic in Scopus being based in China). China, with 55 ethnic minorities carrying distinctive cultures and living in remote areas, has rich resources to develop ethnic tourism [64]. With the rise of domestic tourism, the interest in ethnic minority exoticism by the Han Chinese is increasing [79]. The Chinese government also supports its development and uses it to increase rural incomes and close the rural-urban development gap [80].

Studies on ethnic tourism have been carried out in multiple Chinese provinces, including Hunan [81], Hainan [82], Inner Mongolia [83], Guangdong [84], Guangxi [6], Guizhou [85-87], Sichuan [88], Xinjiang [78], and Yunnan [89-92]. These studies often focus on the local ethnic minorities, socio-cultural impacts, and policies of ethnic tourism. They reveal the challenges in terms of balancing between the protection of ethnic cultures and economic development, perspective of ethnic residents in terms of their desire for wellbeing, and limited control of tourism development [52]. Only a few explore the experience 
and perceptions of tourists, which investigated tourist perceptions of various aspects of ethnic destinations including authenticity, landscapes, attractions, accommodation, services, prices, local interactions, and motivations/intentions to revisit [64,71,78]. All of these studies employed quantitative approaches yet there is still a lack of detailed explanation of the ethnic tourism experience.

\subsubsection{Ethnic Minority Village Tourism}

Ethnic minority villages have abundant and diverse cultures and traditions and have become popular attractions for tourism markets [93]. This form of tourism refers to taking ethnic village communities as destinations, using cultural events and natural scenery as attractions, and emphasizing simplicity and cleanliness [94]. The research topics about ethnic minority villages include basic tourism theory, tourism development, development planning, tourism markets and marketing, as well as community participation in ethnic minority villages. Ethnic village tourism was classified into famous "hot spots", key cultural relics, emerging "hot spots", and undeveloped types according to the development histories and current situations [94]. As the material carriers of ethnic cultures and unique tourism resources, ethnic villages can fully, systematically, and ecologically display customs [95].

As catalysts for economic and sociocultural development in many countries [84], many scholars consider employing minority village tourism as a form of sustainable development. Liang [96] not only pointed out the weaknesses in the development of ecological tourism in ethnic villages but also discussed planning from the aspects of tourism management and improving the product structure of ecological tourism. Zhong and Shen [97] discussed the strengthening of the development of personalized experiences in ethnic villages and the protection of cultural tourism resources as being of significant importance for the sustainable development of tourism in ethnic minority areas. The participation of community residents promotes the sustainable development of minority villages [98].

On the premise of protecting ecological environment and national traditional culture, the development of ethnic village tourism has attracted scholars' attention. Lor, Kwa, and Donaldson [85] studied how ethnic tourism could alleviate rural poverty in Southwestern China. Ren [99] suggested that the sustainable development of ethnic village tourism can only be promoted by balancing the interests of the relevant stakeholders, building a long-term mechanism of checks and balances, and coordinating stakeholder interests. Zhang [100] put forward early warning principles for the sustainable development of ethnic tourism in view of the potential problems. Yang [101] proposed building a compensation mechanism for ethnic culture in tourist villages to promote the effective inheritance of ethnic culture. Liao and Yu [102] put forward the concept of "Green Plus" to facilitate the transformation and upgrading of ethnic village tourism. Gao and Zhou [103] identified the favorable factors for the sustainable development of ecotourism in Yunnan, which delivered positive economic, ecological, and social benefits. $\mathrm{Wu}$ [8] emphasized that the "original ecology" is important for tourists for experiencing and understanding the cultures in ethnic minority villages.

Thoughtful long-term planning is the foundation for realizing the sustainable development of ethnic minority village tourism. Liu and Li [104] outlined strategies for the systematic protection and planning of different types of minority villages, such as livable, natural, ancient, and civilized villages. Wu et al. [105] took a Dong village as a research case and constructed the ideal path and mode for cultural space development of small towns with minority tourism characteristics in China from natural environment, material culture, behavioral culture, and spiritual culture perspectives. Chen and Zhang [106] constructed a traditional ethnic sports culture tourism competitiveness model to enhance the level of tourism competitiveness. 
The markets for and marketing of minority village tourism is another active research area. Zhang and Ren [107] constructed Taobao tourism for ethnic villages and created an export platform for tourism products and services, as well as an effective resource distribution mechanism for ethnic villages in the digital business era. Smartphone apps of the ethnic villages make it easier to access information on them and for consumers to book what they need. They also promote the eco-friendly development of tourism in ethnic villages for the long-run. Nie [108] applied the smart tourism concept to provide comprehensive strategic suggestions for the promotion of tourism services and management in ethnic villages, in order to achieve the transformation of ethnic village tourism and enhance its effectiveness. Lee and Abrahams [109] highlighted that promotional materials are key means to attract tourists.

Resident participation in community-based tourism (CBT) has influenced the promotion of sustainable development [110]. Researchers have found that resident attitudes toward cultural conservation is critical for the development of tourism in ethnic minority tourism [111]. There is greater support for the promotion of cultural tourism when residents feel it is ensuring meaningful community participation in tourism development and operations [112]. Zhou et al. [113] believed that the participation of minority villagers in tourism development included utilization and control of resources, intervention in decision-making and selection processes, benefit sharing, commitment and contribution, capacity-building, self-organizing capabilities, and the application and innovation of local knowledge. Liu [114] proposed market-oriented, government-led, community-centered initiatives with the help of non-governmental organizations (NGOs) and other external driving forces in order to implement and deepen community participation in order to effectively promote the long-term sustainable development of ethnic village tourism. Chen et al. [115] adjudged that the "Langde Mode", with the operation and organization of community guidance and public participation, had fostered the local community's economic, social, and political success.

\subsection{Guizhou and Its Ethnic Minority Villages}

Guizhou is in southwest China, wherein 49 minorities live in the province (Figure 1). It was chosen as the focus for this research because almost all of the Miao people in China reside there [116]. Guizhou also has among the largest populations of the Dong ethnic minority in the country [117]. The Southeast Guizhou Miao and Dong Autonomous Prefecture is located in the southeast of Guizhou and contains several ethnic minority villages, including the Thousand Miao villages Xijiang, Shangzhai Langde, and the Dong Village Zhaoxing (Figure 1). Thousand Miao villages Xijiang consists of more than 10 natural villages built in the mountains, covering an area of about 50 square $\mathrm{km}$. It is the largest Miao village in China (and the world). The Xijiang Miao nationality is one of the important parts of the Miao nationality in southeastern Guizhou, and it is the place where Miao people settled after five major transfers. There are 1285 families in the Thousand Miao villages in Xijiang with a resident population of about 9000 people [118]. The Miao and Dong Autonomous Prefecture is in a middle subtropical monsoon humid climate area. The average annual temperature ranges from 14 to $18^{\circ} \mathrm{C}$. Ethnic minorities have unique cultural characteristics, such as Barrier wine, dances (bronze drum dance, high row lusheng-a reed-pipe wind instrument-dance, and wooden drum dance), Miao ancient songs, and the Dong chorus. Specially, hundreds of people sit at long lines of tables for dining, called the long-table banquet, which is the most vital kind of banquet of Miao people. Other customs and traditions include the poultry ceremony, weddings, the lushing festival, and Miao new year of Miao people. Marking, bridge picnicking, the cattle-welcoming ceremony, new-harvest eating festival, sisters' festival, and Dong year of the Dong people. 


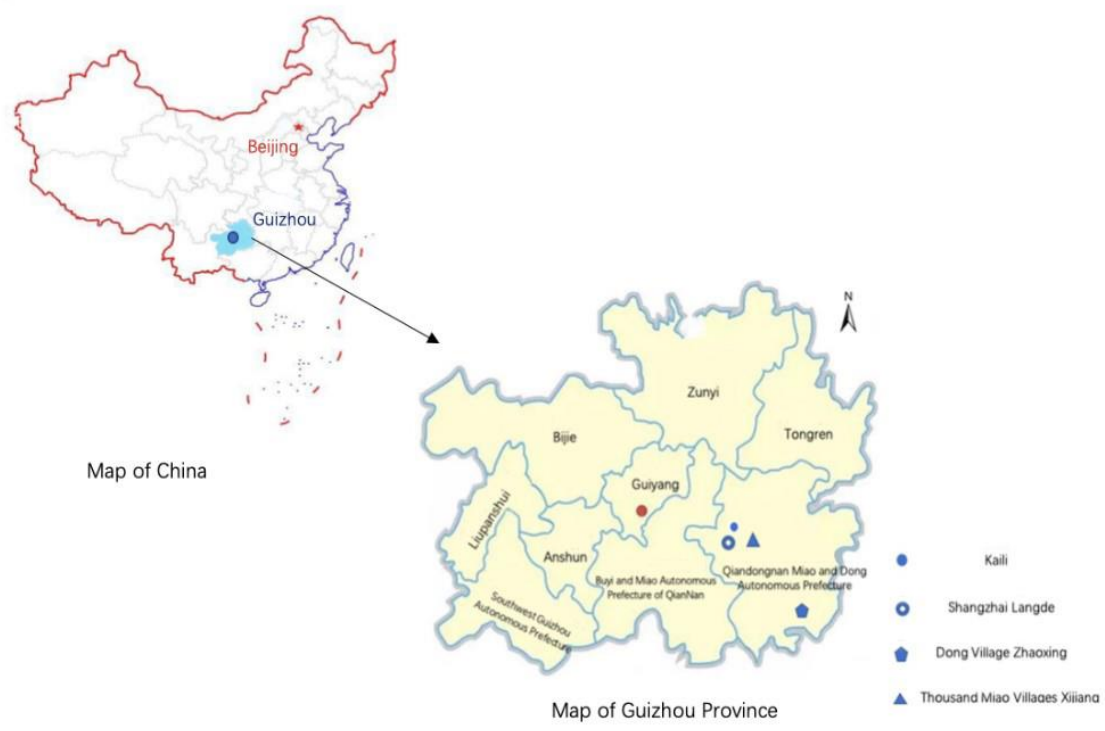

Figure 1. Map of research areas.

Several gaps in the existing research were identified in the foregoing review of the related literature. The current investigation, therefore, uses a qualitative research method, aiming to provide through blog analysis a more comprehensive picture of the ethnic village tourist experience in China. Travel blogs have proven to be credible sources of data for tourism studies [19] and were the data source for this exploratory, qualitative analysis.

\section{Methodology}

\subsection{Subjects}

Ethnic village tourism is a mixture of rural and ethnic tourism, in which tourists go to places inhabited by ethnic minorities for sightseeing and experiencing a unique culture. The ethnic villages have become distinctive tourism attractions, featuring natural scenery, unique landscapes and architecture, and customs. The relatively non-modern, primitive, and unsophisticated lifestyles and natural surroundings offer significant cultural and environmental differences for residents who have lived in cities for most of their lives. The subjects were Chinese domestic tourists visiting the villages in Guizhou Province. This study explored the online travel notes of tourists visiting minority villages from four aspects, and the analysis framework is shown in Figure 2.

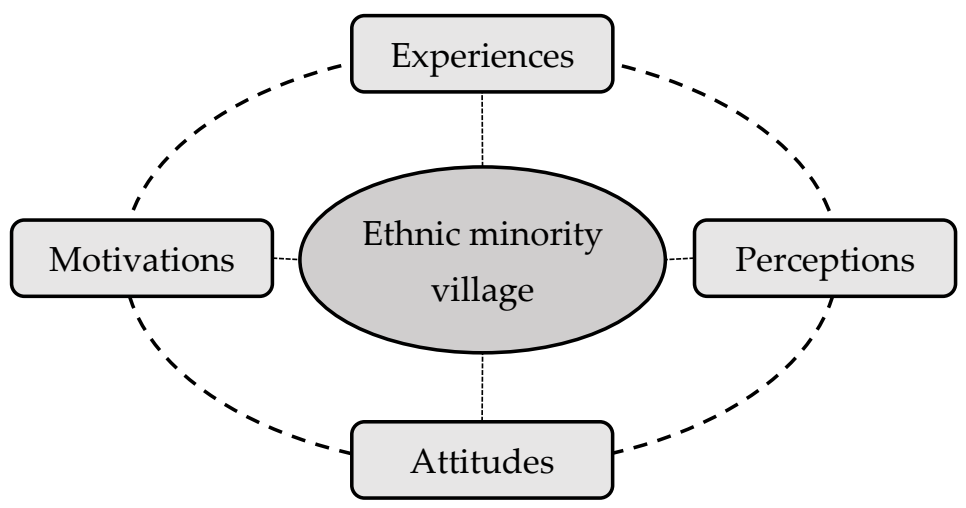

Figure 2. The conceptual framework of analysis.

\subsection{Data Analysis}

Content analysis was used to analyze the information contained in the text of visitor blogs about the ethnic minority villages. Specifically, the ROST Content Mining6 Chinese 
analysis software program was employed to provide content categorization and word frequency statistics. Blogs in the Chinese language about ethnic minority village visits published in Mafengwo.com and Qunar.com were collected and were the raw data for our analysis. Using "Guizhou ethnic village" as the keyword, relevant travel blogs were found on the comment and feedback pages of the two websites. No time period was set for visits in this study. Blogs were chosen that had more than five comments and greater than 1000 views. Travel blogs that were not suitable for the text analysis based on being too short or not related to the research topic were not selected. Finally, there were 81 qualified travel blogs with a total of 106,659 words. The descriptive statistics on high-frequency word counts are shown in Table 1.

Table 1. High-frequency words and expressions.

\begin{tabular}{|c|c|c|c|c|c|c|c|}
\hline Words & Freq. & Words & Freq. & Words & Freq. & Words & Freq. \\
\hline Miao village & 206 & Miao family & 46 & $\begin{array}{l}\text { Simple artistic } \\
\text { style }\end{array}$ & 26 & Delicious & 18 \\
\hline Local residents & 179 & Traditions & 45 & Ancient & 26 & Miao people & 18 \\
\hline Miao & 167 & Zhaoxing & 44 & Accommodation & 26 & Experience & 17 \\
\hline Dong village & 150 & Admission tickets & 43 & Wearing & 26 & Developed & 17 \\
\hline Dong & 130 & Special & 43 & Room & 26 & Women & 17 \\
\hline $\begin{array}{l}\text { Zhaizi (stockade } \\
\text { village) }\end{array}$ & 122 & Langde village & 42 & Customs & 26 & Pretty good & 17 \\
\hline Xijiang & 107 & Hosts & 42 & Song and dance & 25 & Tour & 17 \\
\hline Guizhou & 96 & Natural & 42 & Langde & 24 & Really & 17 \\
\hline Life & 96 & Ethnic minority & 40 & Girl & 24 & Peaceful & 17 \\
\hline $\begin{array}{l}\text { Gulou (Drum } \\
\text { tower) }\end{array}$ & 92 & $\begin{array}{l}\text { Wind and rain } \\
\text { bridge }\end{array}$ & 39 & Photograph & 23 & Public road & 17 \\
\hline Performance & 88 & Viewing platform & 37 & Driver & 23 & House & 17 \\
\hline $\begin{array}{l}\text { Diaojiaolou (pile } \\
\text { dwellings) }\end{array}$ & 78 & Prefer & 37 & Enjoy & 22 & Leishan & 17 \\
\hline Culture & 73 & Scenery & 37 & Elderly people & 21 & Bronze drum & 16 \\
\hline Nationality & 72 & Commercialization & 36 & Museum & 21 & Style & 16 \\
\hline $\begin{array}{l}\text { Xijiang Thousands } \\
\text { of Miao villages }\end{array}$ & 69 & $\begin{array}{l}\text { Lusheng } \\
\text { (reed-pipe wind } \\
\text { instrument) }\end{array}$ & 36 & Commercial & 21 & Slowly & 16 \\
\hline Travel & 65 & Kaili & 36 & Honest & 21 & Unique & 16 \\
\hline $\begin{array}{c}\text { Zhaoxing Dong } \\
\text { village }\end{array}$ & 59 & Hotel & 34 & Folk style & 20 & Unfortunately & 15 \\
\hline Tourists & 59 & Original & 33 & Lively & 19 & Price & 15 \\
\hline Inn & 59 & Different & 32 & Wonderful & 19 & Simple & 15 \\
\hline Village & 57 & Sour soup & 31 & Scenic spot & 18 & Habit & 15 \\
\hline (at) night & 55 & International & 31 & Show & 18 & Dance & 15 \\
\hline Terraces & 53 & History & 30 & Ancient town & 18 & Commercial street & 14 \\
\hline Features & 53 & Original ecology & 30 & Rice wine & 18 & Cloth & 14 \\
\hline Scenic area & 53 & Friend & 30 & Square & 18 & Attract & 14 \\
\hline Dress & 52 & Enthusiasm & 30 & Festivals & 18 & Well arranged & 14 \\
\hline Southeast Guizhou & 50 & Beautiful & 27 & Quiet & 18 & & \\
\hline Architecture & 46 & Guests & 27 & Reserved & 18 & & \\
\hline
\end{tabular}




\section{Results}

\subsection{Tourist Experience}

Along with high-frequency words, the tourist experience also included thematic categories (Table 2). Natural aesthetic mainly contained scenery of ethnic minority villages and terraces. Cultural aesthetic was consisted of ethnic customs, architecture, and folk art, the performances, tickets, hosts, and accommodation in the scenic area were mentioned most often, reflecting tourists' service experience. In addition, it could be seen from the high-frequency words that drivers, bosses, and other service personnel were an important part of tourists' interaction experience. Entertainment experience included tourists taking pictures, shopping, and tasting food.

Table 2. Thematic categories of tourist experience.

\begin{tabular}{|c|c|}
\hline Thematic Categories & Words (Freq.) \\
\hline Natural aesthetic & terraces (53), scenic area (53), scenery (37), scenic spot (18) \\
\hline Cultural aesthetic & $\begin{array}{l}\text { Miao village (206), local residents (179), Dong village (150), village (122), life (96), } \\
\text { Dong village in Zhaoxing (59), Gulou (Drum tower) (92), Diaojiaolou (pile } \\
\text { dwellings) (78), Xijiang Thousands of Miao villages (69), architecture (46), Miao } \\
\text { family (46), Langde village (42), Wind and Rain Bridge (39), history (30), customs } \\
\text { (26), museum (21), folk style (20), festivals (18), ancient town (18), habit (15) }\end{array}$ \\
\hline Service and interaction & $\begin{array}{l}\text { performance (88), inn (59), admission tickets (43), hosts (42), viewing platform (37), } \\
\text { hotel (34), accommodation (26), room (26), driver (23), show (18), public road (17), } \\
\text { price (15) }\end{array}$ \\
\hline Entertainment & $\begin{array}{c}\text { viewing platform (37), sour soup (31), photograph (23), rice wine (18), commercial } \\
\text { street (14) }\end{array}$ \\
\hline
\end{tabular}

\subsection{Tourist Motivations}

The words and sentences in the travel blogs reflecting the reasons why the authors visited the ethnic minority villages were extracted, and thereafter the tourist motivations (Table 3) were divided into thematic categories. These included appreciating historical relics and ethnic buildings, experiencing unique cultural activities, getting close to nature, enhancing feelings, and relaxing. The travel blogs revealed that the different living arrangements and primitive residential environments of ethnic minorities were particularly important to the predominantly Han nationality and city dweller visitors in attracting them. Push motivation factors were also evidenced. Leisure and relaxation reflected the need and desire to escape the frantic pace of city living, as well as to experience more tranquil environments and simpler lifestyles. Appreciating the natural scenery showed that visitors wanted to view and experience the unspoiled ecological environments of the ethnic minority villages. 
Table 3. Analysis of tourist motivations.

\begin{tabular}{|c|c|}
\hline Categories & Blog Verbatim Comments \\
\hline Appreciating historical relics and ethnic architecture & $\begin{array}{l}\text { There is no doubt that the Thousand Miao Village is a beautiful and } \\
\text { spectacular stockade. The Miao Family Wooden Building built on } \\
\text { the mountain, the Miao Family Ah Ma dressed in ethnic embroidery, } \\
\text { and the thousands of lights dotted at night are really very beautiful. }\end{array}$ \\
\hline Experiencing unique folk activities & $\begin{array}{c}\text { Dong people are still relatively simple and hospitable. if you meet } \\
\text { any happy event there, you can wrap a small red envelope, and } \\
\text { then you can experience participating in folk weddings and } \\
\text { enjoying delicious wedding ceremonies. }\end{array}$ \\
\hline Getting close to nature & $\begin{array}{l}\text { Let everyone really feel the green mountains and green waters and } \\
\text { feel the wonderful time of Dong village. }\end{array}$ \\
\hline Enhancing feelings & $\begin{array}{l}\text { Yes, I took my mother, my baby and my luggage to Guizhou. I told } \\
\text { my mother that I would take you back to basics and live in the } \\
\text { original Miao village for a few days. A circle of friends who call } \\
\text { friends has received a quick response from former colleagues and } \\
\text { current neighbors. }\end{array}$ \\
\hline Enjoying leisure and relaxation & $\begin{array}{l}\text { I don't need any reason to walk, maybe I want to relieve my bad } \\
\text { mood and state recently, maybe I just need a strange environment } \\
\text { to settle myself, maybe, where there are so many, maybe, I only } \\
\text { know that you will find the answer you want on the road. If you } \\
\text { want to stay away from a modern city, find a peaceful world, feel } \\
\text { yourself in nature, and return to the beginning, Guizhou is } \\
\text { undoubtedly a good place to go. }\end{array}$ \\
\hline
\end{tabular}

\subsection{Tourist Perceptions}

Words that had nothing to do with tourist perceptions were excluded and the keywords with the highest frequency were selected as being characteristic of tourist perceptions of the villages. The words "Miao village" and "Dong village" had the most mentions, at 206 to 150, respectively (Table 1). These expressions referred to the villages inhabited by ethnic minorities in Guizhou. Thousand Miao villages Xijiang, Dong Village Zhaoxing, Qiandongnan, Xijiang, Zhaoxing, and Langde were the specific places that tourists identified in Qiandongnan Prefecture as where the Miao and Dong ethnicities lived together.

Thousand Miao villages Xijiang ( $n=69)$, Zhaoxing Dong Village (59), and Shangzhai Langde were the villages receiving the most specific mentions (Figure 3). They are well known and tend to be the most impressive to tourists and have become the first choice for people to experience the customs of ethnic minorities in Guizhou. Other specific features frequently cited in the blogs were Gulou (drum-tower, $\mathrm{n}=92$ ), Diaojiaolou (pile dwellings, 78), culture (73), nationality (72), inn (59), Zhaizi (stockade village, 57), terraces (53), and architecture (46). This demonstrated that tourists had a high degree of recognition of the unique characteristics, structures, and living conditions of these Guizhou ethnic minorities. These were the main features recalling their impressions and experiences of the villages. Words such as performance (88), scenic spot (53), traditions (45), admission tickets (43), special (43), hosts (42), and nature (42) were used by tourists to describe the environment, atmosphere, and management of the villages. 


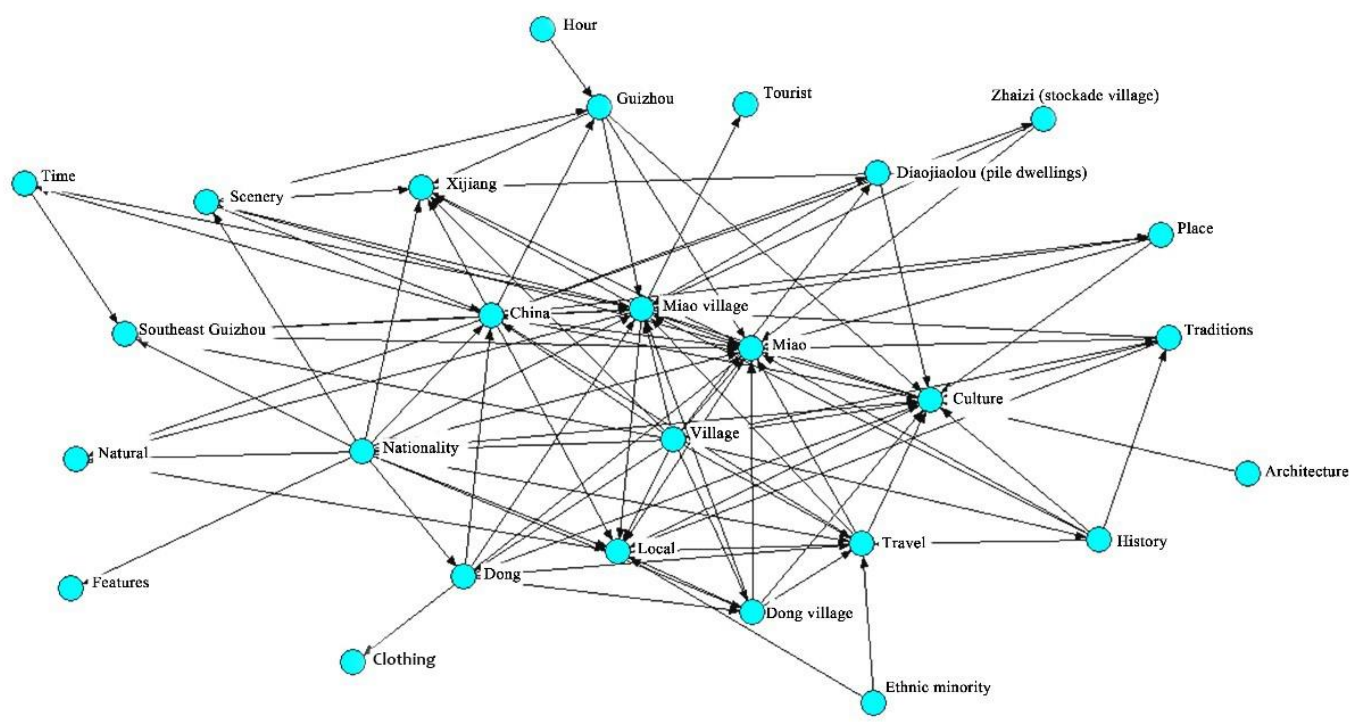

Figure 3. Semantic network analysis of high-frequency words.

Table 4 shows that's tourists' material culture perceptions consisted of food, clothing transportation, and architecture. Tourists' material culture perception included performance, folk art, custom, and products.

Table 4. Thematic categories of tourist perception.

\begin{tabular}{|c|c|c|}
\hline Themes & Categories & Words (Freq.) \\
\hline \multirow{5}{*}{ Material cultural perception } & Food & Sour soup (31), rice wine (18) \\
\hline & Clothing & dress (52), clothes (14) \\
\hline & Transportation & public roads (17) \\
\hline & & Gulou (drum tower) (92), Diaojiaolou (pile dwellings) (78), \\
\hline & Architecture & $\begin{array}{l}\text { Zhaizi (stockade village, 57), wind and rain bridge (39), } \\
\text { ancient town (18), house (17), }\end{array}$ \\
\hline \multirow{4}{*}{ Immaterial cultural perception } & Performance & Song and dance (25), show (18), dance( 15) \\
\hline & Folk art & Lusheng(reed-pipe wind instrument) (36), bronze drum (16) \\
\hline & Custom & $\begin{array}{l}\text { Miao (167), Dong (130), culture (73), nationality (72), ethnic } \\
\text { minority (40), folk style (20), festivals (18) }\end{array}$ \\
\hline & Products & terraces (53) \\
\hline
\end{tabular}

\subsection{Tourist Attitudes}

The results of the attitude analysis are shown in Table 5, including positive attitudes and negative attitudes. On the whole, tourists had good travel experiences and affirmed their choice of travelling to the ethnic minority villages. The positive comments were mainly related to the pristine ecological natural landscapes, customs, and traditions, as well as the friendly residents of Guizhou's ethnic minority villages. Negative evaluations involved the over-commercialization of villages, the "staging" of ethnic customs at scenic spots, and dissatisfaction and regret over the loss of authenticity. In addition, some tourists were not happy with the sub-standard facilities at some scenic spots. 
Table 5. Tourist attitude and verbatim comments.

\begin{tabular}{|c|c|c|}
\hline Attitude & & Blog Verbatim Comments \\
\hline Positive & $\begin{array}{l}\text { a. } \\
\text { b. } \\
\text { c. } \\
\text { d. }\end{array}$ & $\begin{array}{l}\text { I believed that Xijiang Miao Village Scenic Area has perfect service and facilities. } \\
\text { I tasted a lot of delicious food and met many kind people who helped me along the way. } \\
\text { I thought that the sights shocked me deeply. } \\
\text { The veteran driver, who is experienced in driving, is fast and steady like walking on flat ground } \\
\text { on the winding mountain road in the mountain area. } \\
\text { A primitive and unsophisticated village close to the original ecology, I perceived that it still retains } \\
\text { the traditional customs of Miao mountain people for generations and the colorful Miao customs. } \\
\text { I perceived that the air in the mountains is fresh and refreshing, very comfortable. Dong village is } \\
\text { relatively quiet, there are not many tourists, the streets are relatively clean, the consumption is not } \\
\text { expensive, most of them are local residents, and they are relatively comfortable and friendly. }\end{array}$ \\
\hline Negative & $\begin{array}{l}\text { d. } \\
\text { e. }\end{array}$ & $\begin{array}{l}\text { I thought that Miao village has a strong commercial flavor and lacks primitive folk customs. } \\
\text { I perceived that the accommodation conditions here are really not good, and the soft service is } \\
\text { slightly inferior. } \\
\text { I thought that Guizhou's tourist attractions are all far away by car and the transportation is } \\
\text { inconvenient. } \\
\text { I believed that actually chose to go to Guizhou and into the "Badlands". } \\
\text { Ask me what I am most disappointed with Xijiang River. That is, I thought that there is no fruit, } \\
\text { even if there is, it is not fresh. } \\
\text { It's a pity that the organizers are disappointing again, so that most tourists can only sigh! }\end{array}$ \\
\hline
\end{tabular}

\section{Conclusions and Implications}

\subsection{Conclusions and Discussion}

Blog contents, as a robust source of information [119], enabled this investigation to explore motivations, perceptions, and attitudes toward visits to ethnic minority villages. Data were collected from major tourism websites and content analysis was used for word frequency statistics and categorization. Based on the findings of this research, the following conclusions were drawn.

The results showed that tourist experience of minority villages mainly includes natural aesthetic, cultural aesthetic, service and interaction, and entertainment. Tourist motivations of minority villages consist of appreciating historical relics and ethnic architecture, experiencing unique folk activities, getting close to nature, enhancing feelings, and enjoying leisure and relaxation. Specially, over half of the motivations involved humanistic tourism resources in the ethnic minority villages, including historical relics, ethnic architecture, and unique cultural activities. The village settlements, resident lifestyles, characteristic buildings, natural landscapes, and local food were of particular interest to tourists. Visitors were impressed by the tourism attractions, images, facilities, and services in the villages. Moreover, people were satisfied with ethnic minority village tourism, which involves tourists' cognitive and affective processes, as well as their psychological and physiological factors [120]. Attitudes toward the experiences were not only influenced by the attractions and activities but also by the interactions with the local people (including the retailers, hosts, servers, and residents) [54]. Through their interactions with residents, tourists learned more about and more fully experienced the cultures of the minorities. Tourist perception of minority villages was composed of material cultural perception and immaterial cultural perception.

The current research makes a contribution to the literature by documenting tourists actual feelings after visiting ethnic minority villages. Motivations were complex and perceptions were based upon both tangible and intangible cultural heritage. According to Dann's [23] propositions, both push and pull motives were present, with the distinctive characteristics of the villages being particularly strong pull factors.

The gap between expectations and reality affected some visitors' attitudes. A few worried about staged authenticity and over-commercialization of the villages, and this is certainly worthy of future empirical research. 


\subsection{Implications}

Guizhou ethnic minority villages can take measures to better satisfy tourist needs and preferences, upgrade tourism products, and enhance experiences and satisfaction (Figure 4). Three specific initiatives that should be implemented are the following:

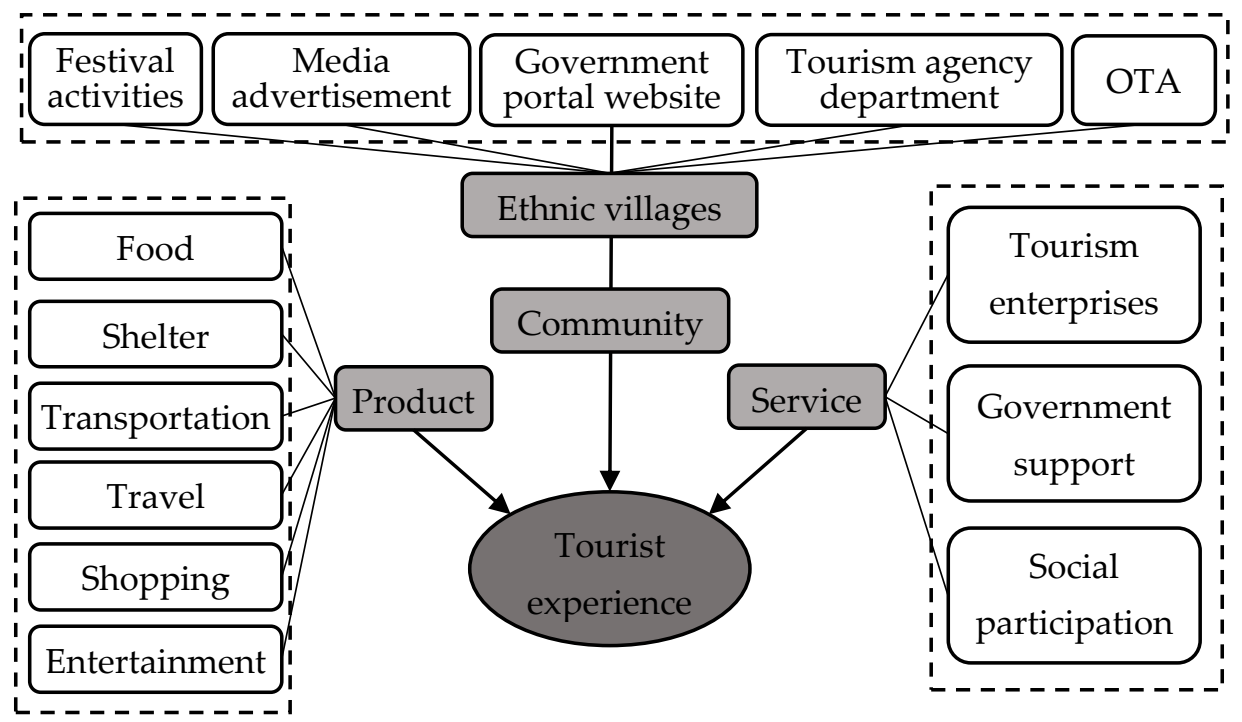

Figure 4. Implications for the development of ethnic minority villages (OTA: online travel agency).

In order to strengthen the use of technology and tourism marketing, ethnic minority village tourism should not only pay attention to maintaining authenticity and traditions but should try to benefit from the support of modern technology. Internet and cloud technology can display and provide virtual experiences of traditional ethnic villages and communities. Greater use of network data technology and big data should be made to analyze visitor motivations, preferences, and consumption behaviors in villages. Online technology and platforms should be used more for marketing activities in cooperation with online travel agencies (OTAs). More promotion is required of tourism products and experiences that match tourist needs and motives and improve marketing effectiveness. Additionally, local governments and relevant departments should actively mobilize supporting resources, more widely publicize local tourism characteristics, and guide and manage tourist demand.

There is definitely scope for further product development and improvements to existing facilities and services. Opportunities include designing locally produced specialty dishes using vegetables, fruits, bacon, salted fish, and herbs, which will further highlight the unique characteristics of local minorities and communities. Greater control and standardization of snacks and special drinks in villages and scenic spots are needed to ensure price transparency, fair and uniform pricing, and elevated hygiene standards. Accommodation standards also need to be more clearly set, and a greater variety of lodging options needs to be provided. High-, medium-, and lower-level residential accommodation is required. Residential accommodation operators should be guided to integrate local minority elements into room decorations and encouraged to create exclusive styles of lodging.

Tourist souvenir sales must be more strictly controlled to eliminate the appearance of high-quality, high-priced, and non-authentic retail items. With the natural scenery and authentic customs of minority villages as the core, tourists should have the feeling of returning to and being close to nature. Sightseeing and deeper leisure and experience tourism must be available. The latter can include demonstrating pure customs, providing easy-to-participate cultural experience activities, and giving tourists more opportunities to integrate into and participate in local life in the villages.

The development of authentic live performances, rather than "staged authentic performances", integrating dance and singing with audience participation, must be given a 
high priority. Government agencies, local community groups, and tourism enterprises should develop more cultural entertainment, conference and exhibition venues, health and wellness facilities and services, and other projects that match market demand and trends.

On the one hand, there should be an emphasis improving the sanitation (e.g., water supply and sewage [121]) and safety of hotel housing or bed and breakfasts, as well as enhancing the comfort of the living environment. There is also a need to upgrade the traffic conditions inside and outside the scenic area, providing convenient travel for tourists. In addition, it would be beneficial to improve the level of logistics to ensure the living needs of tourists. On the other hand, the following factors should also be strengthened: emotional labor/sincerity, quality and professionalism, the role of language, the appeal of performance and spectacle, the usefulness of immersion and participation, the power of authentic local voices, and the management of crowding and close encounters [122].

The most negative evaluations of the minority villages concerned overcommercialization. This requires greater protection of the authenticity of communities in all aspects. Moreover, commercialization needs to be controlled through tighter visitor management systems. For example, for the more mature tourist attractions such as the Thousand Miao villages Xijiang, the number of bars and singing rooms should be limited. Tourist souvenirs should be strictly controlled to eliminate the sale of inauthentic and mass-produced merchandise. Enterprises should educate service personnel to improve service consciousness and quality. Governments should educate villagers in morality [123] or employ them in management positions [124], as well as maintain their sense of pride and identity in their national culture. Further, governments should encourage community residents to participate in local tourism development. Therefore, infrastructure, including hardware infrastructure and soft infrastructure development, needs to be improved, which involves stakeholder networks and embraces competing interests [125].

\section{Limitations and Future Research Directions}

There are several limitations in this research that need to be acknowledged. First, the findings were based on the data from online travel blogs about ethnic minority villages in Guizhou. The representativeness of these blogs needs to be treated with caution as many visitors did not upload trip descriptions.

Second, the current research took the ethnic minority villages in Guizhou as case studies; however, there are 55 minorities living in China with huge regional differences. For example, there are large numbers of ethnic minority villages in Yunnan Province and Western China. The results may be partially biased toward the motivations, cultural perceptions, and attitudes toward these particular ethnic minority villages in Guizhou.

Several suggestions are made for future research to extend this study and overcome its limitations. More empirical research should be conducted on tourists who have visited the ethnic minority villages and those who choose not to visit these communities. The research should be extended to include other ethnic minority villages in China (e.g., in Yunnan, Guangxi, and Sichuan) as well as in neighboring countries including Myanmar, Vietnam, Thailand, Cambodia, Lao PDR (The Lao People's Democratic Republic), and Indonesia. It is conceivable that motivations, perceptions, attitudes, and experiences will vary based upon different cultural and natural environments.

As mentioned earlier, future research needs to deal with over-commercialization and periodic overcrowding at these somewhat fragile venues. The potentially large visitor volumes for villages within China may bring greater economic benefits for ethnic people; however, they might also permanently undermine the cultural fabric of their societies, which may in the long-term cause declining visitation.

Author Contributions: Conceptualization, X.L. and C.X.; methodology, X.L.; software, X.L.; formal analysis, X.L.; investigation, X.L.; resources, X.L., C.X., A.M.M., and T.H.H.N.; data curation, X.L.; writing-original draft preparation, X.L.; writing-review and editing, X.L., C.X., A.M.M., and T.H.H.N.; visualization, X.L.; supervision, C.X. and X.L.; All authors have read and agreed to the published version of the manuscript. 
Funding: This research was funded by the National Natural Science Foundation of China (Grant No. 41971182), Humanities and Social Science Foundation of Ministry of Education of China (Grant No. 19YJAZH097), Postgraduates' Innovative Fund in Scientific Research of Huaqiao University (Grant No. 18011121002) and Ministry of culture and tourism of the people's Republic of China's key research support projects for professional postgraduates in 2019 (WLRCY2019-019).

Institutional Review Board Statement: Not applicable.

Informed Consent Statement: Not applicable.

Data Availability Statement: Not applicable.

Conflicts of Interest: The authors declare no conflict of interest.

\section{References}

1. Wang, H.; Yang, Z.; Chen, L.; Yang, J.; Li, R. Minority community participation in tourism: A case of Kanas Tuva villages in Xinjiang, China. Tour. Manag. 2010, 31, 759-764. [CrossRef]

2. Xiao, Q. A summary of research on ethnic tourism villages in China. J. Southwest Univ. Natl. 2009, 30, $209-212$.

3. Luo, Y. A study on present situation and developing measures of culture tourism in Qiandongnan Dong Area. Guizhou Ethn. Stud. 2004, 03, 118-121.

4. Zhong, J. A Contrastive Research of Tourist Experience Index on the Ethnic Village Tourism of China-Case Study on the Yunnan Nationalities Villages and Xishuangbanna Dai Park; Yunnan University: Kunming, China, 2006.

5. Su, L.J.; Swanson, S.R.; Chen, X.H. Social responsibility and reputation influences on the intentions of Chinese Huitang Village tourists Mediating effects of satisfaction with lodging providers. Int. J. Contemp. Hosp. Manag. 2015, 27, 1750-1771. [CrossRef]

6. Abrahams, R. Tourism and the reconfiguration of host group identities: A case study of ethnic tourism in rural Guangxi, China. J. Tour. Cult. Chang. 2015, 13, 39-55. [CrossRef]

7. Trupp, A. The Development of Ethnic Minority Souvenir Business over Time and Space. Int. J. Asia Pac. Stud. 2015, 11, 145-167.

8. Wu, X. The farmhouse joy (nongjiale) movement in China's ethnic minority villages. Asia Pac. J. Anthropol. 2014, 15, 158-177. [CrossRef]

9. Li, Z.; Zheng, G. On cultural protection and development in the construction of ethnic minority characteristic villages. Soc. Sci. Guangxi 2014, 11, 185-189.

10. Li, Y.J.; Turner, S.; Cui, H.Y. Confrontations and concessions: An everyday politics of tourism in three ethnic minority villages, Guizhou Province, China. J. Tour. Cult. Chang. 2016, 14, 45-61. [CrossRef]

11. Chen, Z.; Wang, H.; Li, L. A study of villagers' perceptions on tourism empowerment in national minority. Commer. Res. 2010, 09, 173-178.

12. Chen, Z.; Yang, G.; Chen, J.; Li, L. Spatial variation of the tourism empowerment perception of ethnic village community residents: A case study of Xijiang Qianhu Miao Village in Guizhou. Trop. Geogr. 2011, 31, 216-222.

13. Rui, L.I.; Dianting, W.U.; Yin, H.; Shan, Y.; Mengshan, W.U.; Zhu, T.; Wang, Y. Mechanism model and demonstration of residents' satisfaction in Guizhou ethnic tourism villages: A comparative study of community-driven, government-driven and enterprise-driven ethnic tourism villages. Acta Geogr. Sin. 2016, 71, 1416-1435. [CrossRef]

14. Maccannell, D. Staged Authenticity: Arrangements of Social Space in Tourist Settings. Am. J. Sociol. 1973, 79, 589-603. [CrossRef]

15. Cohen, E. A Phenomenology of Tourist Experiences. Sociology 1979, 13, 179-201. [CrossRef]

16. Ryan, C. The Tourist Experience: A New Introduction; Cassell: London, UK, 1997; 235p.

17. Godovykh, M.; Tasci, A.D.A. Customer experience in tourism: A review of definitions, components, and measurements. Tour. Manag. Perspect. 2020, 35, 100694. [CrossRef]

18. Walter, P.G. Travelers' experiences of authenticity in "hill tribe" tourism in Northern Thailand. Tour. Stud. 2016, 16, 213-230. [CrossRef]

19. Zhou, L. Hitchhiking tourism and social trust: Exploring Chinese experiences through travel blogs. Ann. Tour. Res. 2020, 81, 102853. [CrossRef]

20. Kim, J.-H. Determining the Factors Affecting the Memorable Nature of Travel Experiences. J. Travel Tour. Mark. 2010, 27, 780-796. [CrossRef]

21. Lee, K.-Y.; Lee, H. Traditional costume experience at a cultural heritage festival. Tour. Manag. Perspect. 2019, 32, 100555. [CrossRef]

22. Crompton, J.L. Motivations for pleasure vacation. Ann. Tour. Res. 1979, 6, 408-424. [CrossRef]

23. Dann, G.M.S. Anomie, ego-enhancement and tourism. Ann. Tour. Res. 1977, 4, 184-194. [CrossRef]

24. Iso-Ahola, S.E. Toward a social psychological theory of tourism motivation: A rejoinder. Ann. Tour. Res. 1982, 9, 256-262. [CrossRef]

25. Pearce, P.L.; Lee, U.-I. Developing the Travel Career Approach to Tourist Motivation. J. Travel Res. 2005, 43, 226-237. [CrossRef]

26. Fodness, D. Measuring tourist motivation. Ann. Tour. Res. 1994, 21, 555-581. [CrossRef]

27. Lin, Y.-H.; Lee, Y.-C.; Wang, S.-C. Analysis of motivation, travel risk, and travel satisfaction of Taiwan undergraduates on work and travel overseas programmes: Developing measurement scales. Tour. Manag. Perspect. 2012, 2-3, 35-46. [CrossRef] 
28. Goeldner, C.R.; Ritchie, J.R.; McIntosh, R.W. Tourism Principles, Practices and Philosophies, 8th ed.; JohnWiley \& Sons: New York, NY, USA, 2000.

29. Goeldner, C.R.; Ritchie, J.R. Tourism: Principles, Practices, Philosophies; JohnWiley \& Sons: Hoboken, NJ, USA, 2003.

30. Farmaki, A. An exploration of tourist motivation in rural settings: The case of Troodos, Cyprus. Tour. Manag. Perspect. 2012, 2-3, 72-78. [CrossRef]

31. Bideci, M.; Albayrak, T. Motivations of the Russian and German tourists visiting pilgrimage site of Saint Nicholas Church. Tour. Manag. Perspect. 2016, 18, 10-13. [CrossRef]

32. Paris, C.M.; Teye, V. Backpacker Motivations: A Travel Career Approach. J. Hosp. Mark. Manag. 2010, 19, 244-259. [CrossRef]

33. Zhang, Y.; Peng, Y. Understanding travel motivations of Chinese tourists visiting Cairns, Australia. J. Hosp. Tour. Manag. 2014, 21, 44-53. [CrossRef]

34. Maoz, D. Backpackers' motivations the role of culture and nationality. Ann. Tour. Res. 2007, 34, 122-140. [CrossRef]

35. Wen, J.; Meng, F.; Ying, T.; Qi, H.; Lockyer, T. Drug tourism motivation of Chinese outbound tourists: Scale development and validation. Tour. Manag. 2018, 64, 233-244. [CrossRef]

36. Mutanga, C.N.; Vengesayi, S.; Chikuta, O.; Muboko, N.; Gandiwa, E. Travel motivation and tourist satisfaction with wildlife tourism experiences in Gonarezhou and Matusadona National Parks, Zimbabwe. J. Outdoor Recreat. Tour. 2017, $20,1-18$. [CrossRef]

37. Watthanaklang, D.; Ratanavaraha, V.; Chatpattananan, V.; Jomnonkwao, S. Measuring the motivation to ride bicycles for tourism through a comparison of tourist attractions. Transp. Policy 2016, 52, 153-163. [CrossRef]

38. Caber, M.; Albayrak, T. Push or pull? Identifying rock climbing tourists' motivations. Tour. Manag. 2016, 55, 74-84. [CrossRef]

39. Marques, C.; Mohsin, A.; Lengler, J. A multinational comparative study highlighting students' travel motivations and touristic trends. J. Destin. Mark. Manag. 2018, 10, 87-100. [CrossRef]

40. Klenosky, D. The "Pull" of Tourism Destinations: A Means-End Investigation. J. Travel Res. 2002, 40, 385-395. [CrossRef]

41. Kulczyk-Dynowska, A.; Gaura, G. Spatial and Financial Aspects of a Protected Area Functioning-The Case of the Gorce National Park. Econ. Reg. Stud. Studia Ekon. I Reg. 2017, 10, 62-74. [CrossRef]

42. Goldstein, E.B. Cognitive Psychology, 3rd ed.; China Light Industry Press: Beijing, China, 2015.

43. Lindsay, P.H.; Norman, D.A. Human Information Processing: An Introduction to Psychology. Science 1971, 174, $683-684$.

44. Jiang, C. The study on the difference of the red cultural perception of domestic tourists-Taking Yan'an red tourism as an example. J. Hebei Univ. Philos. Soc. Sci. 2013, 38, 75-80.

45. Yin, X.; Zheng, X. A study of the tourists' cultural perception of the Three Lanes and Seven Alleys based on network text analysis. J. Beijing Int. Stud. Univ. 2015, 37, 33-66.

46. Su, S.; Sun, C.; Chen, R. Cultural value, perceived value, and consumer decision-making style in China: A comparison based on urbanization dimension. Nankai Bus. Rev. 2013, 16, 102-109.

47. Wu, X.; Li, J.; Jiang, Q.; Luo, Y. Research on the degree of correlation between influencing factors of tourists' shopping behavoir of tourism commodities and visitors' motivations: Taking ethnic village tourism commodity market in the southeast of Guizhou as an example. Ecol. Econ. 2013, 12, 134-138.

48. Zhang, X.; Yang, G.; Zhu, X.; Qin, C. A research of tourist motivation and development strategies to Hmong original ecological cultural villages: A case study in the Xijiang Hmong village of Guizhou province. Guizhou Ethn. Stud. 2015, 36, $144-147$.

49. Sui, L.; Li, Y. Study on difference between expected value and perceived value for culture heritage tourists: A Case study in Xi'an. Sci. Econ. Soc. 2010, 28, 188-192.

50. Wei, X. A study on tourist perception value of ethnic marriage custom culture: A case study of Guizhou ethnic marriage custom tourism. Guizhou Soc. Sci. 2017, 02, 111-116.

51. Ding, Y.; Li, S.; Yanci, W. Perceived value of cultural spacein the mass leisure time-A case study of exhibition in Guangzhou downtown. World Reg. Stud. 2017, 26, 146-157. [CrossRef]

52. Su, M.M.; Long, Y.; Wall, G.; Jin, M. Tourist-community interactions in ethnic tourism: Tuva villages, Kanas Scenic Area, China. J. Tour. Cult. Chang. 2016, 14, 1-26. [CrossRef]

53. Plaza-Mejía, M.N.; Porras-Bueno, N.; Flores-Ruiz, D. The Jungle of Support: What Do We Really Mean When We Say "Residents' Support"? Sustainability 2020, 12, 7795. [CrossRef]

54. Qu, H.; Liang, Y. Research on the image perception of Guangzhou tourism destination based on network travel blogs. Soc. Sci. Guangdong 2017, 06, 202-209.

55. Cai, X.; Lai, Z. Empirical research on visitors of image perception for the landscape of food culture in Guangzhou. Hum. Geogr. 2007, 01, 63-66.

56. Lei, Y.; Zhang, H.; Xu, F.; Liang, H. A cross-cultural comparison of Chinese country image perceptions: A case study of China; UK and USA University students. Tour. Trib. 2015, 30, 23-34.

57. Ajzen, I. The theory of planned behavior. Organ. Behav. Hum. Decis. Process. 1991, 50, 179-211. [CrossRef]

58. Um, S.; Crompton, J.L. Attitude determinants in tourism destination choice. Ann. Tour. Res. 1990, 17, 432-448. [CrossRef]

59. Cho, H.; Joo, D.; Moore, D.; Norman, W.C. Sport tourists' nostalgia and its effect on attitude and intentions: A multilevel approach. Tour. Manag. Perspect. 2019, 32, 100563. [CrossRef]

60. Choe, J.Y.; Kim, S. Effects of tourists' local food consumption value on attitude, food destination image, and behavioral intention. Int. J. Hosp. Manag. 2018, 71, 1-10. [CrossRef] 
61. Bajada, T.; Titheridge, H. The attitudes of tourists towards a bus service: Implications for policy from a Maltese case study. Transp. Res. Procedia 2017, 25, 4110-4129. [CrossRef]

62. Lee, T.H. A Structural Model to Examine How Destination Image, Attitude, and Motivation Affect the Future Behavior of Tourists. Leis. Sci. 2009, 31, 215-236. [CrossRef]

63. Richter, L.K.; Smith, V.L. Hosts and Guests: The Anthropology of Tourism. Pac. Aff. 1979, 51, 711. [CrossRef]

64. Yang, L.; Wall, G. Ethnic tourism: A framework and an application. Tour. Manag. 2009, 30, 559-570. [CrossRef]

65. Smith, V. Power and Ethnicity in "Paradise": Boracay, Philippines. In Hosts Guests Revisited: Tourism Issues 21st Century; CABI: Wallingford, Oxfordshire, UK, 2001; pp. 141-152.

66. Yang, L.; Wall, G.; Smith, S.L.J. Ethnic tourism development: Chinese Government Perspectives. Ann. Tour. Res. 2008, 35, 751-771. [CrossRef]

67. Van den Berghe, P.L.; Keyes, C.F. Introduction tourism and re-created ethnicity. Ann. Tour. Res. 1984, 11, 343-352. [CrossRef]

68. Wood, R.E. Touristic ethnicity: A brief itinerary. Ethn. Racial Stud. 1998, 21, 218-241. [CrossRef]

69. King, B. What is ethnic tourism? An Australian perspective. Tour. Manag. 1994, 15, 173-176. [CrossRef]

70. Lane, B.; Kastenholz, E. Rural tourism: The evolution of practice and research approaches-towards a new generation concept? J. Sustain. Tour. 2015, 23, 1133-1156. [CrossRef]

71. Yang, L. Tourists' perceptions of ethnic tourism in Lugu Lake, Yunnan, China. J. Herit. Tour. 2012, 7, 59-81. [CrossRef]

72. Cohen, E. Ethnic tourism in Southeast Asia. In Tourism, Anthropology and China; Yang, H., Chen, Z., Zhang, Z., Eds.; Yunnan University Press: Kunming, China, 2001; pp. 19-43.

73. Yang, L. Ethnic tourism and cultural representation. Ann. Tour. Res. 2011, 38, 561-585. [CrossRef]

74. Deaden, P.; Harron, S. Alternative tourism and adaptive change. Ann. Tour. Res. 1994, 21, 81-102. [CrossRef]

75. Hughes, G. The cultural construction of sustainable tourism. Tour. Manag. 1995, 16, 49-59. [CrossRef]

76. Moscardo, G.; Pearce, P.L. Understanding ethnic tourists. Ann. Tour. Res. 1999, 26, 416-434. [CrossRef]

77. Zhang, J.; Xu, H.G.; Xing, W. The host-guest interactions in ethnic tourism, Lijiang, China. Curr. Issues Tour. 2017, 20, 724-739. [CrossRef]

78. Yang, J.; Ryan, C.; Zhang, L. Ethnic minority tourism in China-Han perspectives of Tuva figures in a landscape. Tour. Manag. 2013, 36, 45-56. [CrossRef]

79. Graburn, N. Ethnic Tourism in Rural China: Cultural or Economic "Development"? In Ethnic and Minority Cultures as Tourist Attractions; Diekmann, A., Smith, M.K., Eds.; Channel View Publications: Bristol, UK, 2015; pp. 176-187.

80. Chio, J. A Landscape of Travel: The Work of Tourism in Rural Ethnic China; University of Washington Press: Seattle, WA, USA, 2014; Volume 88.

81. Yu, H. A vernacular way of "safeguarding" intangible heritage: The fall and rise of rituals in Gouliang Miao village. Int. J. Herit. Stud. 2015, 21, 1016-1035. [CrossRef]

82. Xie, P.F. Developing Ethnic Tourism in a Diaspora Community: The Indonesian Village on Hainan Island, China. Asia Pac. J. Tour Res. 2010, 15, 367-382. [CrossRef]

83. Fraser, R. Cultural heritage, ethnic tourism, and minority-state relations amongst the Orochen in north-east China. Int. J. Herit. Stud. 2020, 26, 178-200. [CrossRef]

84. Zhuang, L.; Taylor, T.; Beirman, D.; Darcy, S. Socially sustainable ethnic tourism: A comparative study of two Hakka communities in China. Tour. Recreat. Res. 2017, 42, 467-483. [CrossRef]

85. Lor, J.J.; Kwa, S.; Donaldson, J.A. Making ethnic tourism good for the poor. Ann. Tour. Res. 2019, 76, 140-152. [CrossRef]

86. Song, Y.; Yuan, M. Tourism and its impact on Dong traditional music and life in Xiaohuang. J. Tour. Cult. Chang. 2020, 1-16. [CrossRef]

87. Wang, L.; Yotsumoto, Y. A different interpretation from Cornet's on tourism development in an ethnic minority village in China. Asia Pac. J. Tour. Res. 2018, 23, 847-861. [CrossRef]

88. Zhou, Q.; Zhang, J.; Zhang, H.; Ma, J. A structural model of host authenticity. Ann. Tour. Res. 2015, 55, 28-45. [CrossRef]

89. Chen, L. Cultural impact of modernization and tourism on Dai villages in Xishuangbanna, China. Tour. Geogr. 2014, 16, 757-771. [CrossRef]

90. Kolås, Å. Tourism and the Making of Place in Shangri-La. Tour. Geogr. 2004, 6, 262-278. [CrossRef]

91. Morais, D.B.; Dong, E.; Yang, G. The ethnic tourism expansion cycle: The case of Yunnan province, China. Asia Pac. J. Tour. Res. 2006, 11, 189-204. [CrossRef]

92. Zhang, Y.; Lee, T.J.; Xiong, Y. Residents' perception of the influence of luxury chain hotels on ethnic tourism communities. J. Tour. Cult. Chang. 2019, 17, 432-448. [CrossRef]

93. Jin, R. A trial analysis on tour in Guizhou's Villages of national culture. Guizhou Ethn. Stud. 2002, 01, 61-65.

94. Luo, Y. A study on current situation and developing measures of tourism in the ethnic village. Guizhou Ethn. Stud. 2003, 02, 102-107.

95. Li, J. The folkloric, the spectacular, and the institutionalized: Touristifying ethnic minority dances on China's southwest frontiers. J. Tour. Cult. Chang. 2012, 10, 65-83. [CrossRef]

96. Liang, Y. Analysis of development of ecotourism and sustainable development of minority nationality villages. Ecol. Econ. 2007, 05, 113-117. 
97. Zhong, J.; Shen, X. Study on quality of tourists' tourism experience in ethnic villages-A case study of Xishuangbanna Dai Park. Resour. Dev. Mark. 2010, 26, 362-371.

98. Li, G. Dissertation on community residents participation in minority village tourism. Heilongjiang Natl. Ser. 2007, 04, 46-50.

99. Ren, Y. Based on the stakehoder theory studies of ethnic village Tourism development: To Sichuan Gutang Taoping Qiangzhai for example. Guizhou Ethn. Stud. 2013, 34, 112-115.

100. Zhang, Z. An Empirical study on early warning principles of tourism development of ethnic villages. Theory Pract. Financ. Econ. 2015, 36, 136-139.

101. Yang, J. Study on the ethnic culture compensation in tourism village in China. Reform. Strategy 2017, 33, 128-142.

102. Liao, J.; Yu, S. Study on the transformation and upgrading of village tourism in minority areas based on the concept of "Green+". Ecol. Econ. 2018, 34, 102-106.

103. Gao, S.; Zhou, C. Exploration of Poverty Alleviation Based on Ecotourism in Minority Areas of Yunnan Province. Ekoloji 2018, 27, 1105-1113.

104. Liu, Z.; Li, Z. Study on the Protection and Planning of Ethnic Minority Villages in the Process of Urbanization-A Case Study of Guangxi Ethnic Minority Villages. Guangxi Soc. Sci. 2015, 9, 31-34.

105. Wu, Z.; Dai, M.; Wu, S. Cultural change and spatial reconstruction in ethnic minority villages: A case study of the planning and designing of Pingdeng Dong viliage, a characteristic tourist town. Guangxi Ethn. Stud. 2017, 3, 133-140.

106. Chen, W.; Zhang, L. Tourism competitiveness of minority traditional sports culture based on diamond model in Guangxi, Yunnan and Guizhou. J. Guilin.Univ. Technol. 2014, 34, 191-197.

107. Zhang, Z.; Ren, X. On the construction of ethnic village tourism platform in the view of global tourism: A case study of Leishan county. J. Orig. Ecol. Natioal Cult. 2017, 9, 137-144.

108. Nie, X. A study on promotion strategies of ethnic villages tourism from the perspective of intelligent tourism. Guizhou Ethn. Stud. 2018, 39, 171-174.

109. Lee, A.K.-Y.; Abrahams, R.A. Naturalizing people, ethnicizing landscape: Promoting tourism in China's rural periphery. Asian Geogr. 2018, 35, 177-196. [CrossRef]

110. Amin, A.; Ibrahim, Y. Model of Sustainable Community Participation in Homestay Program. Mediterr. J. Soc. Sci. 2015, 6, 539-545. [CrossRef]

111. Yun, H.J.; Zhang, X. Cultural conservation and residents' attitudes about ethnic minority tourism. Tour. Hosp. Res. 2017, 17, 165-175. [CrossRef]

112. Manwa, H. Sustainability Management and tourism impacts on communities: Residents' attitude in Maun and Tshabong, Botswana. Int. J. Environ. Sci. Educ. 2017, 6, 1-15.

113. Zhou, J.; Yang, X.; Zhang, F. Analysis on the characteristics and connotation of ethnic minority villages community participating in tourism development. Heilongjiang Natl. Ser. 2013, 05, 92-97.

114. Liu, W. Difficulties and choices: Community participation in ethnic village tourism. Qinghai Soc. Sci. 2008, 02, 133-135.

115. Chen, Z.; Li, L.; Li, T. The organizational evolution, systematic construction and empowerment of Langde Miao's community tourism. Tour. Manag. 2017, 58, 276-285. [CrossRef]

116. Shi, J. Xijiang Qianhu Miao Village. Available online: https:/ /www.chinahighlights.com/kaili/attraction/xijiang-miao-village. htm (accessed on 20 February 2021).

117. Zhaoxing Dong Village. Available online: https://www.chinatravel.com/southeast-guizhou-attraction/zhaoxing-dong-village/ (accessed on 20 February 2021).

118. Teng, Y.; Chen, S.; Fan, Y. Investigation on commercialization of thousands of Miao village in Xijiang, Guizhou. Mod. Bus. Trade Ind. 2018, 39, 19-20.

119. Oliveira, C.S. My trip in my words: Subjectivities, time(s) and mobilities in slow travel blogs. Time Soc. 2020, $29,223-255$. [CrossRef]

120. Anselmsson, J. Sources of customer satisfaction with shopping malls: A comparative study of different customer segments. Int. Rev. Retail Distrib. Consum. Res. 2006, 16, 115-138. [CrossRef]

121. Kulczyk-Dynowska, A.; Stacherzak, A. Selected Elements of Technical Infrastructure in Municipalities Territorially Connected with National Parks. Sustainability 2020, 12, 4015. [CrossRef]

122. Pearce, P.L.; Wu, M.-Y. Soft infrastructure at tourism sites: Identifying key issues for Asian tourism from case studies. Tour. Recreat. Res. 2015, 40, 120-132. [CrossRef]

123. Fan, L.; Li, Q. Influence of social capital, sense of place on the residents' attitudes toward ethnic village tourism development. J. Zhejiang Univ. Sci. Ed. 2016, 43, 337-344.

124. Massing, K. Safeguarding intangible cultural heritage in an ethnic theme park setting-The case of Binglanggu in Hainan Province, China. Int. J. Herit. Stud. 2018, 24, 66-82. [CrossRef]

125. London, W.R.; Lohmann, G.; Moyle, B.D. Network fragmentation and risk in cruise tourism infrastructure development: Auckland, New Zealand. Case Stud. Transp. Policy 2021, [Epub ahead of printing]. [CrossRef] 